\title{
LEGAL ENFORCEMENT OF STATE AID CONTROL IN THE FIELD OF HEALTHCARE: EXPERIENCE OF UKRAINE IN THE CONTEXT OF EUROPEAN INTEGRATION
}

DOI: 10.36740/WLek202012224

\author{
Antonina G. Bobkova', Andrii M. Zakharchenko ${ }^{1}$, Yuliia M. Pavliuchenko ${ }^{2}$ \\ 'DONETSK LAW INSTITUTE OF MINISTRY OF INTERNAL AFFAIRS OF UKRAINE, MARIUPOL, UKRAINE \\ 2VASYL' STUS DONETSK NATIONAL UNIVERSITY, VINNYTSYA, UKRAINE
}

\begin{abstract}
The aim: The purpose of this article is to concretize the directions of improving legal support of control over the state aid in the field of health care.

Materials and methods: The study analyzed the sources of the European Union law and legislative acts of Ukraine on the provision of state aid to business entities, relevant materials of the Antimonopoly Committee of Ukraine, including more than 20 decisions taken by this body based on the notification review results of the state aid provision in the field of health care. The methodological basis of the research consists of general and special methods of scientific research, in particular, dialectical, analytical-synthetic, system-structural, formal-logical, comparative legal methods.

Conclusions: Based on the results of the study directions for improving legal support for state aid control in public health sector have been proposed, in particular, legal qualification of the activities of health care providers, determining whether certain types of public health activities belong to those that constitute a common economic interest and finalizing the criteria used to assess admissibility of state aid in this area.
\end{abstract}

KEY WORDS: state aid, health care, control

Wiad Lek. 2020;73(12 p. II):2848-2854

\section{INTRODUCTION}

An important task of modern democratic states is to create conditions for the preservation and strengthening of people's health, providing them with high-quality medical services. One of the means of implementing this task is the use of various forms of state support for business entities operating in the healthcare sector. The need to provide such support is due to the fact that health care activities are of great social importance and cannot always be carried out on a purely commercial (market) level since in a socially oriented country every citizen should have the opportunity to receive a necessary treatment regardless of financial capabilities. At the same time provision of state support in this area is associated with the risks of distorting economic competition, unreasonable gain by certain economic entities of competitive advantages over other entities. This, in turn, gives grounds to consider such support as "state aid to business entities", which is subject to control by specially authorized bodies.

In the European Union countries provision of state aid in the health sector with the application of the rules for monitoring such aid is a fairly common practice. So, as of September 2020, the information search system of the European Commission contains information on 120 cases on the provision of state aid (support) in this area [1]. Unlike the European Union countries, in Ukraine the system of control over state aid to business entities was introduced relatively recently. In particular, in accordance with the Association Agreement between Ukraine and the European Union (ratified by Ukraine on September 16, 2014), Ukraine has undertaken to adopt national legislation on state aid, adapting it to the relevant rules of the European Union. The Parties have agreed that they will apply the Articles of Agreement on the state aid matters using as a source of interpretation the criteria arising from the application of Articles 106, 107 and 93 of the Treaty on the Functioning of the European Union, in particular, the relevant jurisprudence of the Court of Justice of the European Union, as well as relevant secondary legislation, framework provisions, guidelines and other existing administrative acts of the Union [2]. In fulfillment of these obligations, the Law of Ukraine "On State Aid to Business Entities" [3] was adopted, the effect of which extends, among other things, to relations on exercising control over the provision of state assistance in the field of healthcare.

The primary experience accumulated in Ukraine in the application of EU rules in the state aid control in the above-mentioned area indicates the existence of problematic legal issues, the solution of which may be of interest both for this country and for other countries practicing state assistance to providers of medical and related to its services. 
The above indicates the relevance of the stated topic and the expediency of its research.

\section{THE AIM}

The purpose of this study is to concretize the directions for improving the legal framework for monitoring state aid in the health sector.

\section{MATERIALS AND METHODS}

To achieve this goal relevant provisions of the Treaty on the Functioning of the European Union were analyzed, as well as the main official documents of the European Commission and the Court of Justice of the European Union, which are important for the legal qualification of certain state aid measures. Critical analysis of the relevant legislation of Ukraine was carried out. Review of the Antimonopoly Committee of Ukraine (hereinafter referred to as the Authorized Body for State Aid) status reports on the provision of state aid to business entities in Ukraine for 2017-2019 was summarized. The content of all decisions taken by the specified authorized body in the period from January 2018 to August 2020 based on the notifications review results on the provision of state aid in the health sector (23 decisions in total) was processed.

In the course of the analysis of the materials general and special methods of scientific knowledge, in particular, dialectical, analytical-synthetic, system-structural, formal-logical, comparative-legal methods were used.

\section{REVIEW AND DISCUSSION}

In accordance with the Treaty on the Functioning of the European Union in its activities the Union respects the obligations of the member countries to define their health policies and to organize and provide health care and medical services. The responsibility of the member states includes management of health services and medical care as well as the allocation of resources dedicated to them (part 7 of article 168). At the same time health sector is a subject to provisions of the same Treaty which establish general principles for the provision of state aid by member states and control over state aid (Articles 107-109) [4].

Taking into account the law of the European Union in the legal systems of the countries concerned, there has been applied an approach, according to which state support of economic entities is the object of control, which meets certain criteria, the presence of which gives grounds to qualify certain support measure as "state aid to a business entity". In particular, in Ukraine, state support is considered state aid if it simultaneously has the following features: 1 ) provided to a business entity; 2) carried out at the expense of the state or local resources; 3 ) creates advantages for the production of certain types of goods or the implementation of certain types of economic activity; 4) distorts or threatens to distort economic competition (Article 1 of the Law of Ukraine "On State Aid to Business Entities").
In case if a certain planned measure of state support of economic entities (including those carrying out activities in the field of health care) meets the above four criteria, then executive authorities or local governments intending to provide such support are obliged to submit notifications of new state aid to the Authorized Body for State Aid. Such state body reviews submitted notifications, establishes affiliation of the proposed state support measure to state aid and decides on admissibility or inadmissibility of its provision, taking into account the legislative requirements.

However, in contrast to the features of state aid enshrined in Article 107 of the Treaty on the Functioning of the European Union in some countries (including Ukraine) there is no mandatory presence of such a qualifying feature of state aid as the impact on international trade. As a result, control is exercised over state aid which does not affect international trade but concerns the state of competition only in domestic commodity markets.

Health care activities are among the economic activities that most often receive notifications of state aid from the State Aid Authority. So, according to the analysis results of the activities of such a body in Ukraine it was found that in 2018-2019 the health care sector entered the top ten spheres of economic activity in respect of which the authorized body for state aid has considered a notification on state aid [5, 6]. From January 2018 to August 2020, this regulatory body adopted:

18 decisions according to which certain measures of state support in the field of health care are recognized as non-state aid (including 5 decisions in 2018; 6 decisions in 2019; 7 decisions in 2020);

5 decisions by which measures of state support in this area are recognized as state aid, which is permissible for competition, provided that its suppliers and recipients fulfill additional obligations determined by the controlling body (including in 2019 - 1 decision; in 2020 - 4 decisions) [7].

The above shows that in most cases applicants incorrectly qualify certain measures of state support, mistakenly considering them to be state aid. At the same time the analysis of the decisions taken by the controlling body that the problematic issues stem from the payment of medical services from various sources. Thus, state and communal health care enterprises (institutions) within the scope of the state guaranteed volume provide certain medical services that are free of charge for patients and financed from the state budget, and have also the right to provide other medical services to patients on a paid basis. Accordingly, in case of providing these enterprises (institutions) with state support in any form the question arises about the legal qualification of such measures. At the same time such a qualification requires clarification of the nature of the activity of the support recipient (economic or uneconomic activity) [8;9].

For the formation of national law enforcement practice it is important to consider the relevant sources of European Union law. From this perspective the Notification from the European Commission on the concept of state aid in accordance with Article 107 (1) of the Treaty on the Functioning of the European Union which, among other 
things, contains a separate subdivision - "Health care" (subsection 2.4), is especially significant. It stipulates that the health systems of different member states of the Union differ significantly. The availability and level of competition between healthcare providers depends on these national characteristics. In some member states public hospitals are an integral part of the national health system and are entirely based on the principle of solidarity (the national health system in Spain is a prime example). These hospitals receive direct funding from social contributions, other government resources and provide their services free of charge to all categories of the population. The European Court of Justice has confirmed that, given the existence of such a system, the organizations concerned are not considered to be economic operators. If such system exists, then even an activity that is inherently economic but carried out for the purpose of providing another non-economic service is not considered an economic activity. An organization that buys goods - even in large quantities - for the purpose of providing a non-economic service is not considered a business entity because it simply acts as a buyer in the relevant market. In addition, it was stated that in many other member states hospitals and other health care providers offer their services for a fee that is paid directly by patients or through their health insurance. In such systems there is a certain level of competition between hospitals in the provision of health services. In this case the fact that the medical service is provided by a public hospital is not sufficient for the relevant activity to be considered uneconomical. According to the explanation of the EU court, medical services provided by private doctors and other specialists for a fee and at their own risk should be considered an economic activity. The same principle applies in the case of pharmacies [10]. A similar position is set out in Notification from the Commission on the application of the European Union State aid rules to compensation granted for the provision of services of general economic interest [11]. At the same time an overview of various models of financing enterprises and healthcare institutions in the EU member states (Germany, Netherlands, Spain, Poland, Czech Republic) is presented rather thoroughly in Section 4 of the Report Study on the financing models for public services in the EU and their impact on competition [12].

To find out whether certain measures to support business entities in the health care sector belong to state aid the legal positions set forth in other sources of European Union law are also important. In particular, the European Commission Resolution SA 39913 (2017 / NN) on the compensation of public hospitals indicates that the EU courts have confirmed: in those systems (in particular health care systems) where services are funded directly from social insurance fees and other public resources, and are also provided free of charge or with a small part of expenses coverage by affiliated persons for basic universal services, the respective organizations do not carry out business activities. The activities of medical institutions which are almost entirely functioning on the principles of solidarity and universality can be considered uneconomical for the purposes of assessing public assistance [13]. Paragraph 39 of General Jurisdiction FENIN Court Statement (T-319/99) determines that under the condition of the existence of a solidarity system, medical institutions are not considered subjects of economic activity [14]. Along with this the decision of Ambulanz Glöckner (C-475/99) of the EU Court of Justice noted that the services of medical organizations provided for a fee from end consumers in the market of relevant medical services are considered an economic activity [15].

At the same time legal qualification of the activities of medical institutions in national health systems, based on the principle of solidarity, is still not unambiguously resolved. Thus, in addressing this issue, Pedro Cruz Yábar focused on the legal position set out in the Judgment of the General Court in the case of the Coordination of Bruxelloise d'institutions sociales et de santé (CBI). In this case the Court agreed with the Commission's decision, which emphasized that any activity involving the supply of goods and services in a given market is an economic activity. Even if medical services were provided almost free of charge (end-users paid only a small part of the costs), it cannot be ruled out that the same services may also be provided by a private operator for a fee [16]. In its judgment the Commission referred to the judgment of the European Court of Justice in the case of Smits and Peerbooms, which applied the following position: the fact that hospital treatment is financed directly by health insurance funds on the basis of agreements and predetermined cost of services does not in any way preclude such activities from the sphere of economic activity. The concept of economic activity does not require that the service be paid for by those to whom it is provided. Payments made by health insurance funds are a reward for the medical services of the hospital that provides them, and which carries out economic activities [17]. In view of this Pedro Cruz Yábar rightly states that the indicated decisions of the Commission and the Court in the CBI case do not agree with the position set out by the Commission in the Communication on the application of the European Union State aid rules to compensation granted for the provision of services of general economic interest. As the interpretation contained in the judgment of the Court of Justice necessarily prevails over the interpretation previously set out in the Commission's Communication, it can be concluded that the interpretation available in the Communication does not currently apply. Hence, in principle, it should be borne in mind that a hospital providing medical services is an enterprise even when those services are not paid for by those who directly benefit from them and/or when the hospital operates in accordance with the principle of solidarity. However, this issue remains open, given the limited number of precedents, and current situation may change in future decisions of the Commission and the Court of Justice [18].

Thus, the above indicates the expediency of clarifying in the official documents of the European Commission its position on the qualification of the activities of health care providers to resolve the contradictions described 
above. In its turn, at the national level, in the explanations of the authorized competition authorities it is advisable to specify the conditions for recognizing state aid measures of state support for healthcare enterprises (institutions), considering the possibility of simultaneous financing of their activities from different sources.

Alongside, there are problems with the qualification of state aid in relation to certain types of economic activities in the field of health care and their classification as those of general economic interest. The legal basis for raising such issues is Article 106 of the Treaty on the Functioning of the European Union, according to which business entities entrusted with the management of general economic interest services or which have features of profitable monopoly are subject to competition rules, provided that the application of such rules does not legally or actually interfere with the performance of certain tasks assigned to them. An explanation of the key concepts underlying the application of state aid rules in compensation for services constituting a common economic interest is set out in the above-mentioned Communication from the EU Commission on the Application of the EU State Aid Rules to compensation provided for the provision of services constituting a common economic interest 2012 / Since 8/02 [11]. In addition, the judgment of the European Court of Justice of 24 July 2003 № 280/00 in the case of Altmark Trans Gmbh, Regierungspräsidium Magdeburg v Nahverkehrsgesellschaft Altmark Gmbh, which sets out the criteria, according to which compensation for business entities for the costs associated with the provision of general services economic interest cannot be considered state aid [19].

As Johan W van de Gronden points out, the Altmark approach could be of great interest for health care, as universal coverage plays a major role in this sector. However, it is strongly depends on how the Community courts interpret the Altmark criteria. If they use a strict reading of the Altmark judgment many national compensation measures will be found incompatible with Article 87 (1) EC. Consequently, proper execution of many PSOs will be put at risk due to the standstill provision of Article 88 (3) EC. Conversely, a flexible interpretation of the Altmark criteria will prevent these problems from occurring [20].

However, there is currently a contradictory approach in national legal systems (particularly in Ukraine). On the one hand, at the legislative level health services are not included in the list of services of general economic interest [21]. On the other hand, in practice, the State Aid Authority recognizes that the establishment of such a list is not in line with European Union rules, according to which compensation for the provision of services, which are of general economic interest, is assessed according to the criteria for such support or is not considered State aid, or is considered State aid that is eligible for competition. Accordingly, there are cases when Authorized Body for State Aid recognizes certain activities related to the field of health care as being of general economic interest [22].

To eliminate this contradiction the initiative of the Authorized Body for State Aid in legislative amendments deserves support, taking into account the above-mentioned Judgment of the European Court in the Altmark case [23].

In the context of abovementioned, one can agree with Vassilis Hatzopoulos, who notes that the application of EU law requires the introduction of the "services of general interest" concept or "public service" in the field of health with a precise definition of its content. This is necessary both to identify which organizations can qualify as "customer organizations" and to apply the Altmark test [24].

Developing the thesis it is worth noting that according to paragraph 46 of the Communication of the EU Commission on the application of the state aid rules of the European Union to compensation provided for the provision of services constituting general economic interest 2012 / C 8/02, in the absence of specific Union rules governing the scope of the SGEI, member states have a wide margin of discretion in designating a service as SGEI and in compensating the service provider. The Commission's competence in this respect is limited to verifying whether a member state has made a manifest error in classifying the service as SGEI and to assess the state aid related to compensation [11].

Taking this into account the achievement of certainty in the application of rules for control over state aid could be facilitated by specifying in the explanations of national competition authorities and bodies implementing state policy in the field of health care, the list of activities in the health sector that can be considered as constituting common economic interest. Besides, at the level of national legislation it is possible to fix a list of special conditions for payment of compensation to healthcare enterprises (institutions) for reasonable costs for the provision of such services. It should be noted, however, that the European Commission is currently assessing the rules for public assistance for health and social services which are of general economic interest. Based on the results of such an assessment the Commission will make a decision to update the SGEI rules applicable to medical and social services [25], which in turn should be taken into account in further formation of national legislation and law enforcement practice.

Another difficult issue related to control concerns the determination of the conditions under which state assistance to business entities in health sector can be recognized as acceptable. Now legal regulation of this issue is based on general (framework) provisions of Article 107 of the Treaty on the Functioning of the European Union which, in particular, states the admissibility of state aid provided in order to promote the socio-economic development of regions in which the standard of living is low or the level of unemployment is high, and to facilitate the development of certain types of economic activities as long as such assistance does not adversely affect the terms of trade.

In the development of these provisions of the Treaty at the national level, the Criteria for assessing the admissibility of state aid to business entities to ensure the development of regions and support for medium and small businesses are approved [26]. Accordingly, the providers of state aid in the field of healthcare emphasize that such aid should 
be aimed at promoting the socio-economic development of regions, and the Authorized Body for State Aid when assessing the admissibility of such aid checks it for compliance with the above criteria [9].

However, it is not always advisable to assess the admissibility of the provision of state aid in the health sector only on the basis of criteria that are calculated to ensure the development of regions. Indeed, the provision of such assistance can be aimed at achieving other goals which are referred to in Article 107 of the Treaty on the Functioning of the European Union. In this regard one of the directions for the development of national legislation on state aid should be further development of criteria for assessing the admissibility of state aid, taking into account the law of the European Union [27] and their application to assess the admissibility of state aid in health sector which aims to solve problems at the national level.

Issues of legal support for state aid include the accumulation of complete and reliable information at the national level in all existing state aid programs in terms of certain areas of economic activity (including health care). For example, in Ukraine there is still no accurate information on state aid which was provided in previous years (which should be a prerequisite for further review of such aid and assessment of its eligibility for competition). The reason for this is the insufficient level of providers awareness on the institution of state aid, improper fulfillment by some of them of the obligation to inform the supervisory authority about new and current state aid, imperfect processing of the information provided, etc.

To eliminate this problem, it is proposed to conduct a comprehensive inventory of all existing programs and measures to provide state support to business entities, the result of which should be the receipt of comprehensive information on the state of the provision of state assistance in general and in the context of individual areas of economic activity, including in the health care sector.

It can be based on an automated information retrieval system set up at the European Union level, which is designed to collect and search for information on state aid decisions, including such a criterion as the economic sector for which aid was provided. At the same time, Human health activities (Q. 86) are separately included in the list of various economic sectors which gives users the opportunity to receive and process information about state aid including this sector [1].

The implementation of these measures at the national level will be useful in exercising control by authorized bodies in the field of state aid, the creation and operation of national information systems for collecting, accumulating and processing information on state aid to business entities.

General issues related to the legal enforcement of state aid control at the level of the European Union and in individual countries were previously considered in the works of Pier Luigi Parcu, Giorgio Monti, Marco Botta [28], Vesna Tomljenović, Nada Bodiroga-Vukobrat, Vlatka Butorac Malnar, Ivana Kunda [29], Marcin Spychała [30], Marek Szydło [31], Marek Rzotkiewicz [32], A.A. Bakalinsky [33],
AE Lillemäe [34] and other authors. Pedro Cruz Yábar [18], Johan W van de Gronden [20], V. Hatzopoulos [24] analyzed various aspects of the application of the European Union rules on the control of state aid in the provision of such aid in healthcare sector.

Research presented in this article made it possible to concretize provisions regarding legal support of control over state aid in this area in such aspects as: legal qualification of the activities of health care providers; determining the affiliation of certain types of activities in the field of health care to those of general economic interest; criteria used to assess the eligibility of state aid in this area; collection and processing of information on state aid programs and measures in the relevant sector of the economy.

\section{CONCLUSIONS}

The study shows that at the level of law and judicial practice of the European Union legal positions on the control of state aid have been formed regarding legal qualification of state aid in the field of health care, and which should be taken into account in the formation of national legislation and law enforcement practice in those countries, including Ukraine, where this issues exist. Wherein perspective areas for improving legal framework for monitoring state aid in the health sector can become:

clarification in the official documents of the European Commission regarding its position on the qualification of health care providers who receive funding from social contributions and other public resources and provide their services free of charge to the public;

specification in the explanations of the authorized national competition agencies of the conditions for recognition as state aid measures of state support for health care enterprises (institutions), taking into account the possibility of simultaneous financing of their activities from different sources;

implementation of the criteria determined by the Decision of the European Court in the Altmark case into national legislation, as well as the establishment of a list of special conditions for payment to health care enterprises (institutions) of compensation for reasonable costs of providing medical and other services of general economic interest;

further development by national authorities of criteria for assessing the admissibility of state aid, taking into account the law of the European Union and their application to assess the admissibility of state aid in the health care sector, which aims to solve problems at the national level;

ensuring the accumulation and publication of reliable information on the programs and measures of state assistance implemented by certain countries in various fields of economic activity, including the health care field.

\section{REFERENCES}

1. State Aid Cases. Available from: https://ec.europa.eu/competition/ elojade/isef/index.cfm?clear=1\&policy_area_id=3. [reviewed 2020.08.10]. 
2. Association Agreement between the European Union and its Member States, of the one part, and Ukraine, of the other part. Available from: https://eur-lex.europa.eu/legal-content/EN/ TXT/?qid=1413961918333\&uri=CELEX:22014A0529\%2801\%29. [reviewed 2020.08.10].

3. Pro derzhavnu dopomohu subiektam hospodariuvannia: Zakon Ukrainy [On State Aid to Business Entities: Law of Ukraine] №. 1555VII of 01.07.2014. Available from: https://zakon.rada.gov.ua/laws/ show/1555-18\#Text. [reviewed 2020.08.05] (Ua).

4. Consolidated version of the Treaty on the Functioning of the European Union. Available from: https://en.wikisource.org/wiki/Consolidated_ version_of_the_Treaty_on_the_Functioning_of_the_European_ Union. [reviewed 2020.08.05].

5. Annual report on granting of state aid to undertakings in Ukraine for 2018. Available from: https://amcu.gov.ua/napryami/derzhavnadopomoga/richni-zviti-pro-nadannya-derzhavnoyi-dopomogi/2018rik. [reviewed 2020.09.10].

6. Annual report on granting of state aid to undertakings in Ukraine for 2019. Available from: https://amcu.gov.ua/napryami/derzhavnadopomoga/richni-zviti-pro-nadannya-derzhavnoyi-dopomogi/2019rik. [reviewed 2020.09.05].

7. Reiestr rishen Antymonopolnoho komitetu Ukrainy shchodo derzhavnoi dopomohy [Register of decisions of the Antimonopoly Committee of Ukraine on state aid]. Available from: http://pdd.amc.gov.ua/registry/ registryofdecision/list. [reviewed 2020.09.05] (Ua).

8. Rishennia Antymonopolnoho komitetu Ukrainy [Decision of the Antimonopoly Committee of Ukraine] No. 640-p of 15.11.2018. Available from: http://pdd.amc.gov.ua/registry/registryofdecision/ list. [reviewed 2020.09.05] (Ua).

9. Rishennia Antymonopolnoho komitetu Ukrainy [Decision of the Antimonopoly Committee of Ukraine] No. 377-p of 18.06.2020. Available from: http://pdd.amc.gov.ua/registry/registryofdecision/ list. [reviewed 2020.09.05]. (Ua).

10. Commission Notice on the notion of State aid as referred to in Article 107(1) of the Treaty on the Functioning of the European Union C/2016/2946. Available from: https://eur-lex.europa.eu/ legal-content/EN/TXT/?uri=uriserv\%3A0J.C_.2016.262.01.0001.01. ENG\&toc=0J\%3AC\%3A2016\%3A262\%3ATOC. [reviewed 2020.09.05].

11. Communication from the Commission on the application of the European Union State aid rules to compensation granted for the provision of services of general economic interest. Available from: https://eur-lex.europa. eu/legal-content/EN/ALL/?uri=CELEX\%3A52012XC0111\%2802\%29. [reviewed 2020.09.05].

12. Study on the financing models for publicservices in the EU and their impact on competition. Available from: https://ec.europa.eu/competition/ publications/reports/kd021641enn.pdf. [reviewed 2020.09.05].

13. State Aid SA.39913 (2017/NN) - Italy Alleged compensation of public hospitals in Lazio. Available from: https://ec.europa.eu/competition/ elojade/isef/case_details.cfm?proc_code=3_SA_39913. [reviewed 2020.09.05].

14. Judgment of the Court of first instance of 4 March 2003 in Case T-319/99. Federación Nacional de Empresas de Instrumentación Científica, Médica, Técnica y Dental (FENIN) v Commission of the European Communities. Available from:https://eur-lex.europa.eu/legal-content/ EN/TXT/?uri=CELEX:61999TJ0319. [reviewed 2020.09.05].

15. Judgment of the Court (Fifth Chamber) of 250 ctober 2001. Firma Ambulanz Glöckner v Landkreis Südwestpfalz. Available from: http:// curia.europa.eu/juris/liste.js?num=C-475/99. [reviewed 2020.09.05].
16. Commission Decision, Case №№ 54/2009 (ex- CP 244/2005) - Belgium Financement des hôpitaux publics du réseau IRIS de la Région BruxellesCapitale, para. 107.

17. Case C-157/99, Smits and Peerboms, [2001], ECR p.I-5473.

18. Pedro Cruz Yábar. The application of State aid rules to the public financing of health care infrastructures. 2013. Available from: http://www.jaspersnetwork.org/download/ attachments/4947983/State\%20Aid\%20Broadband_Guidelines. pdf?version $=1 \&$ modificationDate $=1366385314000 \& a p i=v 2$. [reviewed 2020.09.05].

19. Judgment of the Court of 24 July 2003. Altmark Trans GmbH and Regierungspräsidium Magdeburg v Nahverkehrsgesellschaft Altmark $\mathrm{GmbH}$, and Oberbundesanwalt beim. Available from: http://curia. europa.eu/juris/liste.js?num=C-280/00. [reviewed 2020.09.05].

20. Johan W van de Gronden. Financing Health Care in EU Law: Do the European State Aid RulesWrite Out an Effective Prescription for Integrating Competition Law with Health Care? Availablefrom:http://new.clasf.org/CompLRev/lssues/ Vol6lssue1Article1vandeGronden.pdf. [reviewed 2020.09.05].

21. Pro zatverdzhennia pereliku posluh, shcho stanovliat zahalnyi ekonomichnyi interes: Postanova Kabinetu Ministriv Ukrainy [On approval of the list of services of general economic interest: Decree of the Cabinet of Ministers of Ukraine No. 420 of 23.05.2018.]. Available from:https://zakon.rada.gov.ua/laws/show/420-2018-\%D0\%BF\#Text. [reviewed 2020.09.05] (Ua).

22. Rishennia Antymonopolnoho komitetu Ukrainy [Decision of the Antimonopoly Committee of Ukraine] No. 420-p of 11.06.2019. Available from: http://pdd.amc.gov.ua/registry/registryofdecision/ list. [reviewed 2020.09.05] (Ua).

23. Proekt Zakonu Ukrainy «Pro vnesennia zmin do Zakonu Ukrainy «Pro derzhavnu dopomohu subiektam hospodariuvannia» [The draft Law of Ukraine «On Amendments to the Law of Ukraine «On State Aid to Business Entities»]. Available from: https://amcu.gov.ua/news/ pro-vnesennya-zmin-do-zakonu-ukrayini-pro-derzhavnu-dopomogusubyektam-gospodaryuvannya. [reviewed 2020.09.05] (Ua).

24. Hatzopoulos V. Public procurement and state aid in national health care systems. In E. Mossialos, G. Permanand, R. Baeten, T. Hervey (Eds.). Health Systems Governance in Europe: The Role of European Union Law and Policy (Health Economics, Policy and Management, 2010, p. 379-418). Camridge: Camridge University Press. doi: 10.1017/ CB09780511750496.010.

25. Evaluation of State aid rules for health and social services of general economic interest (SGEI) and of the SGEI de minimis Regulation. Available from: https://ec.europa.eu/competition/state_aid/ legislation/evaluation_sgei_en.html. [reviewed 2020.09.05].

26. Pro zatverdzhennia kryteriiv otsinky dopustymosti derzhavnoi dopomohy subiektam hospodariuvannia dlia zabezpechennia rozvytku rehioniv ta pidtrymky serednoho ta maloho pidpryiemnytstva: Postanova Kabinetu Ministriv Ukrainy [On Approval of the Criteria for Assessing the Compatibility of State Aid to Undertakings to Ensure Regional Development and Support Small and Medium-Sized Enterprises: Decree of the Cabinet of Ministers of Ukraine] No. 57 of 07.02.2018. Available from: https://zakon.rada.gov.ua/laws/show/572018-\%D0\%BF\#Text. [reviewed 2020.09.05] (Ua).

27. Compilation of State aid rules in force. Available from: https://ec.europa. eu/competition/state_aid/legislation/compilation/index_en.html. [reviewed 2020.09.05].

28. Pier Luigi Parcu, Giorgio Monti, Marco Botta. EU State Aid Law: Emerging Trends at the National and EU Level. 2020, $264 \mathrm{p}$. 
29. Vesna Tomljenović, Nada Bodiroga-Vukobrat, Vlatka Butorac Malnar, Ivana Kunda. EU Competition and State Aid Rules: Public and Private Enforcement. 2017, 313 p.

30. Spychała M. Pomoc publiczna w warunkach gospodarki rynkowej. Współczesne problemy ekonomiczne : polityka państwa a proces globalizacji. 2013, nr 139: 238-247.

31. Szydło M. Pojęcie pomocy państwa w prawie wspólnotowym. Studia Europejskie. 2002, nr 4: 34-35.

32. Rzotkiewicz M. Wykonywanie przez Polskę decyzji Komisji Europejskiej nakazujących odzyskanie pomocy państwa w świetle prawa Unii Europejskiej. 2016, 292 p.

33. Bakalinska 0.0. Vdoskonalennia kontroliu za nadanniam derzhavnoi dopomohy subiektam hospodariuvannia [Improving control over the provision of state aid to business entities]. Kherson State University Herald. Series Legal Sciences. 2017; 3: 128-132. (Ua).

34. Lillemiae 0 . Kontseptsiia poniattia «derzhavna dopomoha» [The concept of «state aid»]. Law of Ukraine. 2018; № 5: 46-59. (Ua).

\section{ORCID and contributionship:}

Antonina G. Bobkova: 0000-0002-0834-7514 A,D,F

Andrii M. Zakharchenko: 0000-0002-6359-2475 B,D,E

Yuliia M. Pavliuchenko: 0000-0003-1504-8384 ${ }^{B, D}$

\section{Conflict of interest:}

The Authors declare no conflict of interest.

\section{CORRESPONDING AUTHOR}

\section{Antonina G. Bobkova}

Donetsk Law Institute Ministry of Internal Affairs of Ukraine

Kryvyi Rih, Ukraine

tel: +380676244671

e-mail: bobkova50@gmail.com

Received: 18.09 .2020

Accepted: 27.11 .2020

A - Work concept and design, B - Data collection and analysis, C - Responsibility for statistical analysis, D-Writing the article, $\mathbf{E}$-Critical review, $\mathbf{F}$ - Final approval of the article 